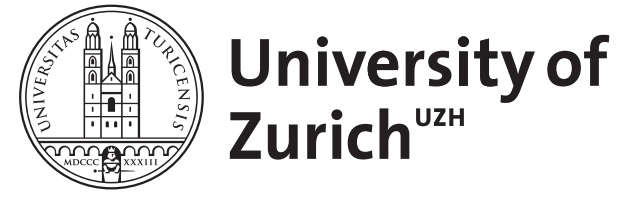

\title{
Histories of ideas and ideas in context
}

\author{
Tröhler, Daniel ; Horlacher, Rebekka
}

\begin{abstract}
History of education was initially and for a long time predominantly written as the history of ideas, developed for teacher education. The early scholars in this field were, as a rule, German theologians and/or philosophers interested in the origin and historical manifestations of eternal (educational) ideas. These ideas were characterized as describing the idea of (morally) the good, most often combined with the idea of the true and connected to the idea of the beautiful. Through the nineteenth century, these histories took different nationalist configurations, first of all in France, then also in England, and the United States, aiming to convince future teachers that the true heroes of these eternal ideas for the good, for the true, and occasionally for the beautiful in postclassical antiquity in fact shared their nationality. It was the consequences of the linguistic turn that challenged this idealism by contextualizing the early ideas of the heroes of education rather than recognizing in them the incarnation of eternal ideas. The research interest focused more and more on discourses or langues of education, styles of thought, and epistemologies and, with this, on questions of power as both restricting and enabling conditions of knowledge production. Ideas in context became a research program that is open to academic history and to philosophy and is thus capable of emancipating the genre from its traditionally assigned role as agent of dominant ideas and preferences and guiding it instead to its analytic potential.
\end{abstract}

DOI: https://doi.org/10.1007/978-981-10-0942-6_2-1

Posted at the Zurich Open Repository and Archive, University of Zurich

ZORA URL: https://doi.org/10.5167/uzh-182537

Book Section

Accepted Version

Originally published at:

Tröhler, Daniel; Horlacher, Rebekka (2019). Histories of ideas and ideas in context. In: Fitzgerald, Tanya. Handbook of historical studies in education : debates, tensions, and directions. Singapore: Springer, 1-18.

DOI: https://doi.org/10.1007/978-981-10-0942-6_2-1 


\title{
Histories of Ideas and Ideas in Context
}

Daniel Tröhler, University of Vienna, Vienna, Austria, daniel.troehler@univie.ac.at Rebekka Horlacher, University of Zurich, Zurich, Switzerland, rhorlach@ife.uzh.ch

\begin{abstract}
History of education was initially and for a long time predominantly written as the history of ideas, developed for teacher education. The early scholars in this field were, as a rule, German theologians and/or philosophers interested in the origin and historical manifestations of eternal (educational) ideas. These ideas were characterized as describing the idea of (morally) the good, most often combined with the idea of the true and connected to the idea of the beautiful. Through the nineteenth century, these histories took different nationalist configurations, first of all in France, then also in England and the United States, aiming to convince future teachers that the true heroes of these eternal ideas for the good, the true, and occasionally for the beautiful in post-classical antiquity in fact shared their nationality. It was the consequences of the linguistic turn that challenged this idealism by contextualizing the early ideas of the heroes of education rather than recognizing in them the incarnation of eternal ideas. The research interest focused more and more on discourses or langues of education, styles of thought, and epistemologies, and, with this, on questions of power as both restricting and enabling conditions of knowledge production. Ideas in context became a research program that is open to academic history and to philosophy and is thus capable of emancipating the genre from its traditionally assigned role as agent of dominant ideas and preferences and guiding it instead to its analytic potential.
\end{abstract}

\section{Introduction}

History of education as a particular kind of research in education emerged in Germany around 1800 mainly for the purpose of improved teacher education. The activists of teacher education reform were university-trained Lutherans, as a rule theologians, philosophers, or philologists, and they conceptualized this new field of interest predominantly as histories of ideas. The focus on ideas rather than on institutions, methods, or materials of education unveils their aspiration for eternity and immutability rather than for historical change, adjustment, or 
substantial development. The ultimate point of reference and departure of these histories of education as histories of ideas was Plato's Ideenlehre, a label characterizing Plato's philosophy that for a long time influenced the English translation 'theory of ideas' before it was suggested to be re-formulated as 'theory of forms' (for instance, Dancy, 2004). The same applies for the French realm: Ideenlehre was first translated as théorie des idées and later as théorie des formes (intelligibles).

The orientation towards Plato's idealism brought forward a kind of history of education as a 'history of ideas,' which Arthur O. Lovejoy later characterized as reducing complexity, as interdisciplinary, and as focusing on particular "unit-ideas" (Lovejoy, 1936, p3) "traveling" across time and space, taking several configurations in different historical contexts in literature, theology, philosophy, or education, but nevertheless progressing. Lovejoy's own prime example of reconstructing historically a unit-idea was the idea of The Great Chain of Being (Lovejoy, 1936). Hence, history of education as a history of ideas was idealistic in two senses - first, by taking its departure from Plato's theory of ideas (and its translation into Christianity), and second, by retracing the trajectories of those Platonic ideas across time and space by basically identifying and portraying in Christianity those 'great' men determined to be closest to those supreme idea(l)s.

This somewhat static point of departure of the history of education as a history of ideas became more dynamic in the wake of Hegel's philosophy of history. Accordingly, history of ideas became less restricted to retracing where and when those ideas popped up in 'great men' across history and dealt more with understanding their appearances in a teleological way. This teleology had clear nationalist implications, as it was believed that the implementations of these ideas had taken place in Germany. This nationalist imagination of the history of ideas supported the ongoing inclusion of the subject 'history of education' in teacher education curricula, as teachers were more and more acknowledged to be major bearers in the process of nation building, particularly after the three Prussian Wars (1864-1871) and the founding of the German Reich in 1871.

By that time, in the last third of the nineteenth century, the genre 'history of education' had already transcended German borders, at first often in the form of translations or compilations of German publications but also, as in the case of France, in nationalist opposition to Germany. As a result, the major characteristics of the German historiography, its moralidealistic orientation, and its nationalistic teleology, remained the historiographic template 
internationally for clearly over one hundred years, as a rule isolated from international research, from the empirical turn in education research, and in particular from the development in historical scholarship after the linguistic turn. As the authors of these histories of education proved to be rather incompetent to realize the vulnerability of the national, idealistic, and moralistic focus of their histories of education, the genre lost its significance in teacher education. This decline, however, opened the doors for alternative research agendas, such as comparative and international, social and institutional, (new) cultural, gender and feminist, new material, colonial and post-colonial approaches (as to be found in this section of the handbook).

These alternative research approaches indicate that with perhaps the exception of Germany, where the traditional genre of history of education as a history of ideas foremost for the purpose of teacher education is still being advocated (Seel and Hanke, 2015; Tenorth, 2016), international research on the history of education has clearly started to emancipate itself from its conditions of origin. However, this does not necessarily mean that the effectiveness of the meanwhile demised genre has disappeared, because due to the lack of suitable alternatives, the ongoing need for historical self-reassurances entices many educationalists to draw on established patterns of historical styles of thought. By referring to the historiographic potential of the linguistic turn and its focus on understanding ideas in their context rather than in the assumed (teleological) eternity, this entry will provide evidence of valuable alternatives to these obsolete historiographies of decontextualized, eternal ideas.

Accordingly, the entry is divided into five parts. First, it focuses on the emergence and establishment of the history of education as a history of ideas in Germany after 1800 (1.), and then on its firm establishment towards 1900 (2.). Subsequently, it refers to the linguistic turn and its challenge to the idealistic conception of ideas (3.) and designs research prospects for histories of 'ideas in context' (4.). The concluding chapter deals with 'ideas in context' in the history of education and will include some prospects following the contextual turn in the history of ideas of education research (5.).

1. The emergence and establishment of history of education as history of ideas in Germany after 1800 
The emergence of history of education as a particular kind of research in education is culturally embedded in the blend of what is called German new humanism and German idealism, an (early) nationalist stance of the German Lutheran intelligentsia that was skeptical about Western science and political ideals such as constitutionalism and republicanism. It interpreted ancient Greek art (sculpture), poetry (epics), and philosophy (foremost Plato) as the acme of spiritual expression (Geist), which was read in the language of Lutheran Protestantism and increasingly also of German nationalism.

Plato's transcendent idealism, according to which ideas exist independently as entities that are ontologically superior to the sensually discernible earthly objects, and with its strict imperative with regard to the implementation of the former, matched the radical dualistic Lutheran worldview that sharply separated the inner and the outer world and that defined the principal superiority of the inward realm as well as the essence of being German. An outstanding figure in this idealistic German-Lutheran process of finding national selfreassurance in Greek philosophy in general and in Plato in particular was the Lutheran theologian Friedrich Schleiermacher, who translated, introduced, and commented on Plato's major dialogues in three volumes (each volume contains two books) between 1804 and 1828 . Schleiermacher thereby helped to pave the way for the particular German Lutheran interpretation of Plato's pre-Christian philosophical idealism, suggesting a reading of Plato's essential educational-epistemological shift called psyches periagoge (literally: the transformation of the soul) as educationally constituted inward purification of the soul (Bildung) and, by that, accepting implicitly the authoritarian and anti-democratic aspects of Plato's political philosophy and taking strict social inequalities not only for granted but as best for social life itself, which again was interpreted as German national life, as Fichte had made clear in his famous nationalist Addresses to the German Nation, first published in 1808.

Accordingly, the first published history of education-expressis verbis as history of ideaswas published in 1813 by a typical representative of these intellectual elites, Friedrich Heinrich Christian Schwarz, who was a Lutheran minister, theology professor, and head of the normal school in Heidelberg. In the introduction to his textbook written for the purpose of teacher education at the normal school, Schwarz asserts that the crucial ideas of education had been discovered in classical antiquity and had then been disseminated through Christianity as "deepest sources" for an inward moral-mental cultural education (Geistesbildung) and thus acted as a "sacred powers" of the "genius of mankind" (Schwarz, 1813, vol. 1, pIV). According to Schwarz, and in line with the historiographic belief of his time, these spiritual 
ideas are expressed by outstanding or even selected men: "A man appears, and a new era begins" (pV). Yet, the notion of a "new era" could be misleading, for what it indicates is a new approach to implementing the eternal ideas once discovered in antiquity (pVI).

Accordingly, history is in itself a teacher, for it reveals beyond the changing material conditions of life the "deeper essence," the effective spirit (Geist), which unfolds in a Platonic way the trinitarian "ideas of the good, the true, and the beautiful" as expressions of human perfectibility (Schwarz, 1813, vol. 1, p3). A thorough history of education would have to consider all the different materializations and configurations through time and space and therefore would have to be designed as "cultural history" (p4), but the essence is still to focus on what is to be revealed as the "history of the educational idea" (p6) - not of ideas, plural, but of "the idea," singular, personified by magnanimous persons giving culture a new momentum and a "better spirit." Schwarz labels them as "educators on a large scale" (p7). Their genius may be asleep in particular times in human history, but then they break out anew in devoted people who intervene by word and deed. Precisely these exceptional persons, bearers and implementers of true ideas and sanctified by genius, are the objects of this particular field of educational research: History of education as a history of ideas examines how these magnanimous persons expressed and implemented these eternal ideas in education and thus in their contemporary culture and now serve as models for prospective teachers.

Schwarz's two-volume textbook on the history of education was pioneering. There had been former attempts at the history of education but not in the form of monographs. A prime example is an appendix in the fifth edition of the standard work on education of the time written by the Lutheran theologian August Hermann Niemeyer and first published in 1796. As Schwarz did, Niemeyer, too, assumed that the "general principles of education" are not changeable but that they find different forms of expression throughout history (Niemeyer, 1806, p415). National characters and national habits are mere "material" modifications of these principles, and with regard to education as a theory, psychology, and ethics, the English, French, and German thinkers of the eighteenth century were leaders (p415). Yet, Niemeyer had no doubt that the truly leading nation with regard to an education theory and as an academic science was Germany, and in particular the German Protestants (p419).

According to some historians, Niemeyer's attempt had been too short a work to be satisfying, and Schwarz's two volumes had been too much like a textbook for use in teacher training, as the historian Johann Friedrich Cramer criticized (Cramer, 1832, pX) in the first of his two 
volumes on the history of education (which, however, never went beyond antiquity). But Cramer's historicist attempt was not to become a dominant model in the establishment of the history of education; rather, it was the moralist approach by German Pietist Carl Georg von Raumer, who was committed to Schwarz's account (Raumer, 1843, pVIII). Raumer emphasizes the moral practicability of history of education in teacher education. In the introduction to the first of the four volumes of his history of education, Raumer (1843-1855) admits that one may indeed expect from a historian an "objective depiction ... free from love and hate" but that he himself would not intend to be free of them and that with regard to advocacy he would not claim objectivity either (pVII). Raumer therefore purposefully acts as a judge in order to encourage the reader to focus on "important educational topics." By depicting in this history of education the "ideals and methods" of the selected "outstanding educators" (pVI), teachers would be encouraged to compare their idea(l)s and practices with those of the depicted idols ( $p$ VII).

Raumer starts his history of education not with antiquity but with the Italian Renaissance (of the ideals of antiquity), a necessary precondition to understand "the history of German education" (Raumer, 1843, pVI). The history of education, Raumer continues, has to envisage in a Platonic-idealistic way those ideals of education that dominate a people in the course of their development and also the practices that in the different epochs of this development are applied to implement these ideals (pVI). These ideals are best identified in "outstanding men," "personifying these ideals" and "exerting the greatest influence on education," even if "they themselves are not educators" (pVI). In any case: "A great example triggers emulation [the teacher] and gives his (self-)assessment higher laws" (pVI).

Raumer's history of education proved to be extremely important, as it not only served as a source for different translations and was newly edited even in the early twentieth century but also served the subsequent histories in their moralist commitment, even if they became teleological and thus more nationalistic, which in turn eased their firm establishment in the curricula of teacher education in the Western world around 1900.

2. Firm establishment of history of education in the last third of the nineteenth century

Raumer's rather unintellectual history of ideas as a sequence of 'great men' embodying eternal idea(1)s was consistently Protestant, and before even the fourth volume of this oeuvre 
was published in 1855, a three-volume Catholic counterpart was starting to be published, constructed in the same, person-centered way, by Johann Lorenz Ludwig (Ludwig, 18531857), but including Catholic educators as well. But just around that time, in the middle of the nineteenth century, Hegelianism began to exert its historiographical attraction, according to which history is still idealistic, a history of the Geist, but more organic, encompassing, and foremost teleological. Hence, the strictly person-centered histories of education by Raumer and Ludwig, which both enjoyed several new editions, needed to be underlaid and ennobled by a particular philosophy of history, for instance in the four-volume history of education by the Protestant Hegelian Karl Schmidt, which started with the German idealistic PlatonicHegelian premise that God's nature reveals itself to humanity in the course of human history "as reason, beauty, and morality" (Schmidt, 1860, p1).

According to this Hegelian approach, world history is defined as the history of the human spirit in its development (Schmidt, 1860, p2), to be reconstructed by the frame of the organic and teleological system of reasoning labeled 'culture-epoch theory,' which assumed an analogy between the phylogenetic development of the race and the ontogenetic development of the individual; accordingly, the "oriental people" are the children, the ancient Greeks and Romans the younglings of history, and "the Christian" is the real man harmoniously interwoven with the outer world (p2), whereby there is a dividing line symbolized by the Lutheran Reformation (p33). The analogy between the phylogenetic development of the race and the ontogenetic development of the individual led Schmidt and his followers to assume anthropologically that the human nature (of the individual) would be the ideal guideline for education; however, this nature was not equated with biological (or social) nature but rather with the spirit in its developmental potential. The aim of education is still Platonically the "true, good, and beautiful" (p5); therefore, the history of education is in its essence the history of the ongoing realization of this spirit, whereby Germany, "the land of thoughts," represents the "acme" of this teleological process (p47) seeking to represent the godlike harmony of the mind, religiosity, morality, and beauty and bringing humankind "closer to divinity" (p50).

The productivity of German historians of education by shortly after the middle of the nineteenth century is impressive; over 5,000 printed pages of certainly different but as a rule idealistic, moralistic, national, and more and more national-teleological histories of ideas of education had been published. The sheer amount of work was more an expression of the authors' intention to identify themselves in a Hegelian, nationalist making sense of the world as being at the top of a long development than an expression of their willingness to be really 
useful in teacher education or to be historiographically accurate. The histories simply contained too much information, and this was the time when those more or less academic histories had themselves to be educationalized in the form of easy to read, short compilations. The first such compilation was published in 1863 by Theodor Ballien; it was a "guideline for teachers and learners," as the subtitle stated, "compiled from previous histories" (Ballien, $1863)$.

The last third of the nineteenth century witnessed the results of a transnational dissemination of German History of Education and at the same time the configuration of national idiosyncrasies of this field of research. History of education as a particular kind of interest in education had emerged in the United States, for instance, in the context of its educational endeavors of nation-building starting in the 1830s, and the model for both-more institutionalized teacher education and history of education as a curricular subject in teacher education - was Germany, more precisely Prussia. It is therefore no coincidence that the first monograph in the United States, titled History of Education, was written by an ethnic German Moravian Lutheran clergyman and professor of German languages at the theological seminary in Gettysburg, Pennsylvania, Henry Immanuel Schmidt (Smith, 1842). Schmidt based his historical account largely on Schwarz's History of Education.

When Smith's $10^{\text {th }}$ edition was published in 1858, Henry Barnard had begun to publish, in his American Journal of Education, English translations of large extracts of Raumer's History of Education. Even though Barnard was drawing upon Raumer's pietistic interpretation of education, there was a change, insofar as in contrast to his German colleagues, Barnard was a lawyer and politician and was heavily engaged with school reform that was not half as selective as the German system and that cared much less about social stratification than about unification. It was also Barnard who promoted a second American monograph (next to Schmidt's) on the history of education, Linus Pierpont Brockett's [using the pseudonym Philobiblius] History of the Progress of Education (Philobiblius, 1860). Brockett, a physician, still drew on Schwarz and Niemeyer, but he also included the French historiographies, such as that by archivist and historian Antoine Vallet de Viriville, and he also urged that the "complete history of education in the United States is yet to be written" (p6). Brockett at least devoted his last chapter to a short history of North American education (p279-291), followed by some statistical data (p293-296). 
The one French author to whom Brockett referred, Antoine Vallet de Viriville, indicates a shift in educational historiography. Written in the wake of the 1848 unrests, Vallet de Viriville's History of Public Education and Instruction in Europe and Foremost in France focused - in contrast to the German historiographies - almost strictly on France and not on educational ideas but on knowledge and its transmission in public instruction (Vallet de Viriville, 1849, p1), a focus that had also been characterized in the very first historical account of public instruction in France, written in 1816 by the later eminent education politician, French Protestant (Hugenot) François Guizot and titled Essay on the History and on the Current State of Compulsory Education in France. French historiography was not so much a history of ideas as it was in Lutheran Germany, but it was still idealistic and interpreted the French 'heroes' of school reform and instruction and thus of knowledge and institutions as national idealists. The histories were written as a rule by (often Huguenot) lawyers, historians, and educational policy makers, quite in contrast to the Lutheran philosophers, theologians, and philologists in Germany, the bearers of these idealistic ideas as the basis of historiography.

This interest in effects of reform ideas in the past started to be reflected in American historiography, for instance in the third American education history, A History of Education by literary scholar Franklin Verzelius Newton Painter, who drew on Schmidt's abovementioned Hegelian History of Education. It was published with an introduction by the famous St. Louis Hegelian, William Torrey Harris. Like Schmidt, Painter builds on human nature as divine potential, but he also emphasizes the utility of schooling, for "human development school be combined with practical wisdom; the school should be the natural introduction into active live" (Painter, 1886, p3), and the essence of schooling is acquiring knowledge (p4-5). Yet, Painter aligned himself with the German (that is Schmidt's) anthropological culture-epoch theory (p5). It is not that there were no "great thinkers" in the past, such as Plato, but since "his view remained without any perceptible effect upon Grecian education," he can be "passed over briefly" (p61).

Over time, American historiography found its own national configuration by incorporating French styles of historiographical reasoning. Robert Herbert Quick's conclusion in 1868 that "on the history of Education, not only good books, but all books are in German, or some other foreign language" (Quick, 1874, pIV) had led him to publish his Essays on Educational Reformers based on German models. But at that time, in the context of the German-French tensions shortly before the Franco-Prussian War in 1870/71, the nationalist agenda became 
explicitly promoted. The French Academy of the Moral and Political Sciences had launched a prize competition, because in its opinion, educational reflection in France was too strongly oriented to "our foreign nations" and thus the "tradition of our history," and the "national spirit" was in danger of becoming forgotten (Gréard, 1877, p345). The prize winner, published in Paris in 1879, was a two-volume work titled The History of the Educational Doctrines (Ideas) in France Since the Sixteenth Century, encompassing almost 1,000 pages and starting with some 55 pages dedicated to the Greeks, the Romans, and the Middle Ages, before focusing on early French ideas from Rabelais, Montaigne, or the Renaissance (Erasmus and Ramus). The author was Gabriel Compayré, who at this time held a chair at the University of Toulouse. As a confessed republican and French Protestant, Compayré worked towards laicization of the French school system. In the foreword to the book, he wrote that the historical volumes had been written for the purpose of discovering abiding truths in the movement and progress of French educational thought and of making them fruitful for a theory of education. Already in the second paragraph, it is clear that this effort also contained polemics against Germany: "Let us not believe that education is the exclusive property of Germany" (Compayré, 1879, pI). Four years later, Compayré published a handier version for teacher education that included also British and American authors such as Herbert Spencer, Alexander Bain, and Horace Mann (Compayré, 1883). And another three years later, William H. Payne, the first holder of a chair in education at any university in the United States, translated and annotated Compayré's book (Compayré, 1886); this publication proved to be extremely successful.

The German historiography was unimpressed by these French or American alternatives. Enthusiastic in their nationalist aspirations by the founding of the German Reich in 1871, schooling and teacher education expanded, and within two years, four new textbooks had been published, all in the style of a history of ideas, fueled by Greek idealism and finding its fulfillment in Germany. And in a comparative way, the French-with some 10 years delayused schooling and enhanced teacher education as a core means of building the French nation in the realm of the Third Republic. Whereas the German histories focused on Greek origins and German heroes, the French focused almost exclusively on French authors as bearers of the 'essential'(French) ideas in their historical trajectories (Tröhler, 2006).

3. The linguistic turn and the challenge to the idealistic conception of ideas 
Around 1900, a good century after its emergence as a particular kind of interest in education, history of education had become a firm part of teacher education in the different national realms of the Western globe. It was as a rule idealistic, universal in its aspiration, nationalmoral in its content, and pedagogical in its style; it aimed at educating devoted prospective teachers as bearers of the 'national spirit' that governed the structural architecture and curriculum of the respective school systems. Institutionalized in this way, history of education as an authoritative curricular subject in teacher education remained rather unchanged up to at least the 1970s.

By the time that Lovejoy theorized the particular historiographic style of the "history of ideas," French and American linguistics and a bit later the English philosophy of language worked on what in the early 1950s would be called the 'linguistic turn,' which fundamentally questioned the previously taken-for-granted assumption according to which objects (nature or ideas) are ontologically separated from subjects (researchers). In Geneva, the French-speaking linguist Ferdinand de Saussure had introduced in 1916 the fundamental distinction between paroles (utterances) and langues (language as particular systems of meaning resulting from human interaction) as two aspects of langage, language as anthropological fact. Whereas any utterance depends on the language as a system understood as a cultural deposit, it nevertheless is true that, historically speaking, the language as a system resulted from mutual uses of utterances. That is, languages as systems are cultural products and are thus subject to change over long periods of time (de Saussure, 1959). Obviously, understanding is not limited to the hermeneutics of the paroles but to the contextualization of understanding a parole in the langue from which it derives.

Whereas de Saussure introduced the analytic distinction between paroles and langues in his general linguistics, modern comparative linguistics was developed in North America, deriving from the differences between standard European and indigenous languages. Two outstanding figures were the ethnologist Edward Sapir and his student Benjamin Lee Whorf. What is known in research as the Sapir-Whorf hypothesis indicates that thinking and thus perception of the world is significantly shaped by the language in which we think - that is, in that which de Saussure had called langue (as system): "We see and hear and otherwise experience very largely as we do because the language habits of our community predispose certain choices of interpretation" (Sapir, 1929, p210). The very fact that different languages had partly very different grammatical structures is the reason why so many different perceptions of the world exist, urges Whorf: "We are thus introduced to a new principle of relativity, which holds that 
all observers are not led by the same physical evidence to the same picture of the universe, unless their linguistic backgrounds are similar, or can in some way be calibrated" (Whorf, 1956, p214).

In the 1950s, when the Sapir-Whorf hypothesis was broadly discussed and the term linguistic turn was coined, the English philosophy of language claimed the idea that words not only display facts but they in fact $d o$ something beyond displaying. In his analysis of everyday language, mainly in his posthumously edited Philosophical Investigations, Austrian-born Ludwig Wittgenstein discovered that modifications in the usage of language (shift in terminology or in linguistic costumes) did not simply mean modifications in the way of talking but rather in the way of behaving or acting; "the meaning of a word is its use in the language" (Wittgenstein, 1953, §43): The meaning of utterances is defined by the context, and uttering is a part of a concrete culture (\$23), or: "Words are also deeds" (\$546). In other words, concepts never describe ideas; rather, they 'invent' them in the context in which they were uttered.

A year before publication of Wittgenstein's Philosophical Investigations, the English philosopher Johan Langshaw Austin was named chair of moral philosophy at Oxford University, where he focused further on the productivity of language and became, as the father of speech act theory, an icon of the linguistic turn. Austin's lectures series at Harvard University (1955) and the University of California, Berkeley (1958-59) became the classic work How to Do Things with Words, published posthumously (Austin, 1962). Austin's major concern was to prove that the major pastime of philosophy from Plato to Wittgenstein had been to formulate statements that turned out to be either true or false. By instancing familiar examples, Austin shows that language does not simply 'describe' or 'state' (truly of falsely) but in fact does something new, such as for example the wedding vow in church, which transforms a woman into a wife and a man into a husband.

Hence, statements are in fact speech acts, because they do not merely describe but rather effectuate things. Any speech act consists of three aspects. The first is the locutionary aspect, the performance of a linguistic utterance (phonetics, grammar, semantics). The second is the illocutionary aspect, indicating the speaker's intention or purpose with his or her statement. And the third is the perlocutionary aspect, which is the effects of the statement on the receiver. Hence, statements are not simply true or wrong descriptions of something, be it nature or (eternal) ideas, but productions of meaning in particular contexts. For political and 
educational historiography, particularly the illocutionary aspect became crucial, for it prevented research from searching for "abiding truths" (see Compayré, 1879, pI) in a text by indicating the intentions that an author might have had with the linguistic potentials of his or her time (that were at his or her disposal). Historiography would have to focus, then, on the question of what the author did when he or she acted, in speaking or writing, within the linguistic potential of a time.

Against the background of the linguistic turn, the claim for or the assumptions of transcendent ideas and thus of eternal ideals is itself a historical act and not a timeless fact. Ideas are now inscribed in utterances that derive their normative power in normative systems that are, in the end, historically and culturally contingent and therefore also, with regard to legitimacy, a matter of power. With this insight, 'history of ideas' is potentially freed from identifying ideas with indisputable truths as well as from reconstructing the historical trajectories of these ideas as a chronology of their realization or implementation by outstanding heroes. Historical research becomes historical and less moral, a field of investigation or inquiry and not of (moral) instruction.

\section{The linguistic turn and 'ideas in context'}

Although research in education was for a long time, and to some degree up to today, hesitant to acknowledge the creative potential of the linguistic turn and its new understanding of 'ideas,' philosophers and then (political) historians have been much more open to it. As early as in 1967 Princeton philosopher Richard Rorty edited the volume The Linguistic Turn: Essays in Philosophical Method (Rorty, 1967) containing important texts on analytic philosophy and claiming the need to re-discuss unresolved questions since antiquity, and in 1975, the Canadian philosopher Ian Hacking asked the question Why Does Language Matter to Philosophy? (Hacking, 1975). By that time, however, the linguistic turn had transcended the disciplinary borders of both linguistics and philosophy and had been implemented productively in historical research, prominently in what has come to be called 'the Cambridge School.'

It is assumed that the first text of the Cambridge School was Quentin Skinner's article Meaning and Understanding in the History of Ideas (Skinner, 1969), and the outstanding feature of the Cambridge School is the book series Ideas in Context, which since 1984 has 
published monographs devoted to reconstructing historically intellectual traditions and the emergence of academic disciplines and their proceedings, aims, and vocabularies by contextualizing them within their historical epoch in a way that allows recognition of idealistic and institutional alternatives to dominating performances. Thereby, the artificial and unproductive separation between history of philosophy, the individual history of sciences, the histories of knowledge and fictions are being dissolved. Lovejoy's historiographical methodology expressed in the "unit-idea" is criticized by Skinner, who argues that such a procedure indicates a "reification of doctrines" that "give rise ... to two kinds of historical absurdity" (Skinner, 1969, p11): for one, "the tendency to search for approximations to the ideal type yields a form of non-history which is almost entirely given over to pointing out earlier 'anticipations' of later doctrines, and to crediting each writer in terms of this clairvoyance," and then for another, "the endless debate ... about whether a given idea may be said to have 'really emerged' at a given time, and whether it is 'really there' in the work of some given writer" (p11-12).

The historiographical catchword in the light of the linguistic turn is ideas in context, releasing historiography from both chronologies of intellectual performances of eternal ideas and ideas of more or less linear progresses, and introducing contextual historicity to historical research by looking at linguistic arsenals (or: langues in de Saussure's sense)—providing historical actors of a given time to do both, interpreting circumstances in a particular way and formulating respective responses to them. The idea of 'ideas' becomes earthly, historical, contextual, and the authority of particular systems of ideas over others becomes a matter of power and dominance.

Accordingly, the research can either focus on the moyenne durée of particular langues as linguistic systems and their adaptability over a longer time period, as John G. A. Pocock does, or focus on 'troubled' contexts in which the traditionally dominant linguistic conventions or langues prove to be unable to interpret the circumstances and by that offer new or altered langues to start to dominate the interpretation of the world, as Quentin Skinner does. The latter focuses, for instance, on the emergence of modern individual liberalism in the wake of the French Revolution, which is interpreted as a new set of linguistic conventions or codes by which the classical understanding of the ideas of liberty and virtue were displaced or at least suppressed: "The ideological triumph of liberalism left the neo-roman theory largely discredited" (Skinner 1998, pX). Hence, Skinner is interested in discontinuities in the dominant ways of interpreting the world by means of the illocutionary force of the respective 
speech acts (utterances or paroles): "I confess that I am less interested in such continuities myself than in the discontinuities to be found within our intellectual heritage" (p111); history then becomes a sort of archeology that gives us new options to act by virtue of providing overviews over (linguistic) opportunities for action: "One corresponding role for the intellectual historian is that of acting as a kind of archeologist, bringing buried intellectual treasure back to the surface, dusting it down and enabling us to reconsider what we think of it" (p112).

In contrast (or in addition) to Skinner's interest in times of transformations, Pocock's approach, based on de Saussure's distinction between langue and parole, is focused on the moyenne durée of the langues as deposits of concrete paroles (utterances) in concrete historical situations. In early years, Pocock had labeled these langues-following Thomas S. Kuhn - as "paradigms." Thereby, Pocock identifies the ideological language deposit (langue) behind a sentence or a word (parole), the former giving the latter its particular meaning. However, these langues are themselves changeable over time, as they are being 'used' by uttering people. Langues are therefore one of the "primary contexts in which an act of utterance is performed," as Pocock says, but also in interaction with the paroles: "For anything to be said or written or printed, there must be a language to say it in; the language determines what can be said in it, but is capable of being modified by what is said in it; there is a history formed by the interaction of parole and langue" (Pocock, 1987, p20).

Despite the somewhat different (or complementary) approaches and interests, Skinner and Pocock are in agreement insofar as they share an interest in the language of classical republicanism, according to which political freedom of the polis is closely tied to the virtues of its (free) citizens as a particular kind of desired behavior. These ideas had been (re)formulated in educational languages and fostered or implemented institutionally for many centuries in the different configurations of those political entities labeling themselves as "free states" or free republics, not only in antiquity but in the Renaissance, in the Swiss Reformation, in parts of the English and Scottish Reformation, in the Swiss Enlightenment, and in the United States of America. Their core concerns addressed ideas of freedom, common-good orientation, good citizenship, patriotism, and steadfastness, but also ideas of corruption, commerce, and effeminacy. Classical republicanism and civic humanism are essentially educational projects, yet they have been ignored as such by both sides, political philosophy and education research. 
5. 'Ideas in context' in the history of education: Conclusion and future directions

The linguistically inspired historiographical approach of the Cambridge School triggered, in the field of political thoughts, a vast array of significant research in the Anglophone, Italian-, French-, and Spanish-speaking worlds, but less so in the German-speaking world, where reception of antiquity remained Platonic-idealistic, new humanistic, and precisely not civic humanistic. Accordingly, relevant discussions, for instance about Machiavelli, which are crucial in classical republicanism research, are hardly to be found, although Machiavelli's work is being interpreted as transmitting ancient Greek ideals into modernity, serving as the ideological background of the founding fathers of the United States of America (Pocock, 1975); Pocock even talks about a "tunnel history" of the langue of classical republicanism (Pocock, 1979, p104) from the ancient Greeks to the United States, a notion that caused the suspicion that Pocock indeed argued for a transcendental linguistic philosophy without any historical anchorage, which Pocock clarified, however (Pocock, 1987).

Even though the content focus of the Cambridge School—classical republicanism of civic humanism in its colorful trajectory over the centuries - includes the close relationship between political constitution, freedom, and (political) virtue and thereby touches upon core educational questions, historical research in education has only exceptionally focused on authors such as Machiavelli (Tröhler, 2003) and has started only slowly to gain acknowledgement in historical research on the educational past. German education historiography has almost completely ignored the intellectual and historiographic prospects following the linguistic turn (an exception is Overhoff, 2004), in contrast to the Anglophone realm (for instance, Cohen, 1991): Focusing research on langues behind the paroles was assessed as "linguistic archeological excavations of and through contemporary educational discourse and as allowing non-linear historiographies, going behind Whig and Marxist interpretations" (Claxton, 2012, p179). The linguistic turn was interpreted as providing an alternative to the two dominant traditions, the Anglophone interpretation of the history of ideas as idea of progress and the Marxist interpretation of a social history (see also Roldán Vera, 2014), even as a new way of teaching history of education (Acosta, 2017), precisely because language did not depict the world (or eternal ideas) but configured it (Parra-León and Marín-Díaz, 2016). 
How empirical or historical the idea of 'ideas' is, and thus is also a question of cultural power, has been addressed in international comparative research collaborations focusing on the configuration of ideas (as cultural practices) in the interrelation between republic(anism) and education and schooling (Tröhler, 2009; Tröhler, Popkewitz, and Labaree, 2011) or on transatlantic performances of educational ideas in the intersection of paroles of langues (Tröhler, 2011). Its focus was on one side on ancient republicanism based on virtues and how it was received in the Swiss Reformation and its effects, which was, in contrast to the German Reformation, strongly political, whereas German Lutheranism remained political indifferent; accordingly, one Reformation developed specific educational doctrines of political virtues, whereas the other Reformation materialized itself theoretically in the realm of inwardness and Bildung. However, the eminent concept of political virtue was not transcendent but rather contextual: Rousseau's idea of (political) virtue was differently configured from Pestalozzi or Thomas Jefferson's idea, and the idea of Bildung was differently theorized within the 200 years of its appreciation of inward perfection (Horlacher, 2016). The langues provid(ed) the need to express in paroles particular ideas of political virtue in one trajectory of Protestant thought, and of inward perfection in the other, but the concrete formulation changed over time and context and affected in their effective performance the configurative power of the langues.

With the exception of the historiography in Germany, the potential of the linguistic turn and its inherent approach to contextualizing (educational) ideas has been acknowledged in many parts of the world, particularly in the Nordic, Anglo-Saxon, and Hispanic worlds, especially as a means to understand how the idea of education and (modern) curriculum became tangible in the dialectic between the ancient anti-commercial concept of virtue and the emergence of the commercial society in the long eighteenth century (for instance, Valero, 2017). Besides the political implication, religion has received more attention in the analysis of dominating educational langues (Osterwalder, 2006), for instance in modern republics such as Argentina (Gomez Caride, 2013; Friedrich, 2014) or in the context of formulating educational theories against the background of social and cultural power relations (Popkewitz, 2018). Beyond the European and the American realms, the strategy of analyzing educational ideas in the intersection between paroles and langues has been applied to China in the book China's Educational Language (Zhao, 2018).

Given this fundamental contextualization of educational ideas in linguistic styles of reasoning that interpret living conditions in particular ways, history of education as history of ideas has 
good prospects. It will never replace the role of the idealistic history of education that was obviously capable of covering the pastoral desires for eternal truth, be it static or Hegeliannationalist, but it will be able to provide alternative trajectories, context-bound, forgoing the moralist self-assurance that characterizes education research in toto, including the so-called empiricist research agenda and its preference for large-scale assessments. History of education as history of ideas in context provides the recontextualization of educational ideas as driving powers for school developments but also of education research and the rise and fall of its competing doctrines defining what 'good research' is. Against this background, the contextual approach in the history of ideas can be interpreted as "the key to self-awareness itself" (Skinner, 1969, p53), an indispensable desideratum to conduct education research in a field that has been eminently moralistic and nationalistic, to free education research from its assigned role as being an agent of implementation (of whatever ideas are dominant at a given time) and to guide it to its essential task, which is to critically analyze claims for agency.

\section{References}

Acosta F. Ensinar história da educação: Reflexões em torno de uma proposta. História da Educação 2017; 21(52):295-311.

Austin JL. How to do things with words. Second edition. Cambridge: Harvard University Press; 1962.

Ballien T. Abriss der Geschichte der deutschen Pädagogik, insbesondere des deutschen Volksschulwesens. Ein Leitfaden für Lehrende und Lernende. Nach den vorzüglichsten pädagogischen Geschichtswerken zusammengestellt. Stuttgart: Belser; 1863.

Claxton JC. Language excavation for the purpose of analyzing curriculum conversation:

Reviewing Daniel Tröhler's Languages of Education: Protestant Legacies, National Identities, and Global Aspirations. Journal of Curriculum and Pedagogy 2012; 9(2):176179.

Cohen S. The linguistic turn: The absent text of educational historiography. Historical Studies in Education/Revue d'histoire de l'education 1991; 3(2):237-248.

Compayré G. Histoire Critique des Doctrines de l'Éducation en France depuis le Seizième Siècle. Paris: Hachette; 1879.

Compayré G. Histoire de la pédagogie. Paris: Delaplane; 1883.

Compayré G. History of pedagogy. Translated, with an introduction, notes, and an index by WH Payne. Boston: D.C. Heath \& Co; 1886. 
Cramer JF. Geschichte der Erziehung und des Unterrichts in welthistorischer Entwickelung. Geschichte der Erziehung und des Unterrichts im Alterthume. 1. Praktische Erziehung. Eberfeld: Carl Joseph Becker; 1832.

Dancy R. Plato's introduction of forms. Cambridge: Cambridge University Press; 2004.

Friedrich DS. Global microlending in education reform: Enseñá por Argentina and the neoliberalization of the grassroots. Comparative Education Review 2014; 58(2):296-321.

Gomez Caride E. Governmentality and religion in the construction of the Argentinean citizen. European Education 2013; 45(3):85-98.

Gréard O. Rapport sur le concours ouvert dans la section de morale (Prix Bordin). Histoire critique des doctrines de l'éducation en France depuis le $\mathrm{XVI}^{\mathrm{e}}$ siécle a nos jours. Séances et travaux de l'adacémie des sciences morales et politiques 1877; 37:345-388.

Hacking I. Why does language matter to philosophy? Cambridge: Cambridge University Press; 1975.

Horlacher R. The educated subject and the German concept of Bildung: A comparative cultural history. New York: Routledge; 2016.

Lovejoy AO. The great chain of being: A study of the history of an idea. Cambridge: Harvard University Press; 1936.

Ludwig JL. Grundsätze und Lehren vorgüglicher Pädagogiker von Locke an bis auf die gegenwärtige Zeit. Three volumes. Bayreuth: Grau'sche Buchhandlung; 1853-1857.

Niemeyer AH. Beyträge zur Geschichte der Pädagogik und Didaktik. In: Niemeyer AH, editor. Grundsätze der Erziehung und des Unterricht für Eltern, Hauslehrer und Schulmänner, 3. Teil. Halle: beym Verfasser; 1806.

Osterwalder F. Die Sprache des Herzens. Konstituierung und Transformation der theologischen Sprache der Pädagogik. In: Casale R, Tröhler D, Oelkers J, editors. Methoden und Kontexte. Historiographische Probleme der Bildungsforschung. Göttingen: Wallstein; 2006.

Overhoff J. Quentin Skinners neue Ideengeschichte und ihre Bedeutung für die historische Bildungsforschung. Jahrbuch für historische Bildungsforschung 2004; 10:321-336.

Painter FVN. A history of education. New York: Appleton; 1886.

Parra-León GA, Marín-Díaz D. De la metáfora del perfeccionamiento humano al aprendizaje permanente: el desdoblamiento del concepto de educación. Cadernos de Educação 2016; 318.

Philobiblius [Brockett LP]. History of the progress of education. New York: A.S. Barnes \& Burr; 1860. 
Pocock JGA. The Machiavellian moment: Florentine political thought and the Atlantic republican tradition. Princeton: Princeton University Press; 1975.

Pocock JGA. Reconstructing the traditions: Quentin Skinner's historians' history of political thought. Canadian Journal of Political and Social Theory 1979; 3(3):95-113.

Pocock JGA. The concept of a language and the métier d'historien: Some considerations on practice. In: Pagden A, editor. The languages of political theory in early-modern Europe. Cambridge: Cambridge University Press; 1987.

Popkewitz TS. Reform and making human kinds: The double gestures of inclusion and exclusion in the practice of schooling. In: Hultqvist E, Lindblad S, Popkewitz TS, editors. Critical analyses of educational reforms in an era of transnational governance. Dordrecht: Springer; 2018.

Quick RH. Essays on educational reformers (1868). Cincinnati: Robert Clarke\&Co; 1874.

Raumer KG von. Geschichte der Pädagogik: vom Wiederaufblühen klassischer Studien bis auf unsere Zeit, four volumes. Stuttgart: Samuel Gottlieb Liesching; 1843-1855.

Roldán Vera E. La perspective de los lenguajes en la historia de la educatión. Ariadna histórica. Lenguajes, conceptos, metáforas 2014; 3:7-14.

Rorty RM, editor. The linguistic turn: Essays in philosophical method. Chicago: University of Chicago Press; 1967.

Sapir E. The status of linguistics as a science. Language 1929; 5(4):207-214.

Saussure F de. Course in general linguistics (1916). Baskin W, translator, Meisel P, Saussy H, editors. New York: Columbia University Press; 1959.

Schmidt K. Die Geschichte der Pädagogik in weltgeschichtlicher Entwicklung und im organischen Zusammenhange mit dem Culturleben der Völker, three Volumes. Cöthen: Paul Schettler Verlag; 1860-1862.

Schwarz FHC. Geschichte der Erziehung nach ihrem Zusammenhang unter den Völkern von alten Zeiten her bis auf die neueste, two volumes. Leipzig: Georg Joachim Göschen; 1813.

Seel NM, Hanke U. Historische Pädagogik: die Geschichte der Erziehung und Erziehungswissenschaft. In: Seel NM, Hanke U, editors. Erziehungswissenschaft. Berlin: Springer; 2015.

Skinner Q. Meaning and understanding in the history of ideas. History and Theory 1969; $8(1): 3-53$.

Skinner Q. Liberty before liberalism. Cambridge: Cambridge University Press; 1998.

Smith HI. Education. Part I: History of education. Part II: A Plan of culture and instruction.

New York: Harper \& Brothers; 1842. 
Tenorth HE. Historische Bildungsforschung. In: Tippelt R, Schmidt-Hertha B, editors. Handbuch Bildungsforschung. Wiesbaden: Springer; 2016.

Tröhler D. Republikanische Tugend und Erziehung bei Niccolò Machiavelli und im Selbstverständnis des Schweizer Stadtbürgertums des 16. Jahrhunderts. In: Musolff HU, Göing AS, editors. Anfänge und Grundlegungen moderner Pädagogik im 16. und 17. Jahrhundert. Köln: Böhlau; 2003.

Tröhler D. The formation and function of histories of education in Continental teacher education curricula. Journal of the American Association for the Advancement of Curriculum Studies 2006; 2:1-17.

Tröhler D. Between ideology and institution: The curriculum of upper-secondary education. Journal of Curriculum Studies 2009; 41(3):393-408.

Tröhler D. Languages of education: Protestant legacies, national identities, and global aspirations. New York: Routledge; 2011.

Tröhler D, Popkewitz TS., Labaree DF, editors. Schooling and the making of citizens in the long nineteenth century: Comparative visions. New York: Routledge; 2011.

Valero P. Mathematics for all, economic growth, and the making of the citizen worker. In: Popkewitz TS, Diaz J, Kirchgasler C, editors. A political sociology of educational knowledge: Studies of exclusions and difference. New York: Routledge; 2017.

Vallet di Viriville A. Histoire de l'instruction publique en Europe et principalement en France. Paris: Administration du moyen age et de la renaissance; 1849.

Whorf, BL. Science and linguistics (1940). In: Carroll JB, editors. Language, thought, and reality: Selected writings of Benjamin Lee Whorf. Cambridge: MIT Press; 1956.

Wittgenstein L. Philosophical investigations. Anscombe GEM and Rhees R, editors. Oxford: Blackwell; 1953.

Zhao, W. China's education, curriculum knowledge and cultural inscriptions: Dancing with the wind. New York: Routledge; 2018.

\section{Cross-references}

Springer: "Please login to the project website on SpringerReference.com and download a current table of contents. Include a list of related entries in this cross-reference section that may be of further interest to your readers"

Keywords (History of schooling, history of education, history of philosophy, linguistic turn) 